\title{
Comparison of Definitions of Multiple Drug Resistance to Antibiotics and Its Alternative Multiple Antibiotic Resistance and Their Methodological Critical Analysis
}

\author{
Antibiyotiklere Çoklu Ilaç Direnci ile Çoklu Antibiyotik Direnci Tanımlarının Karşılaştııılması \\ ve Bunların Yöntemsel Eleştirel Analizi
}

\author{
(1) Nermin SAVAŞAN ${ }^{1}$, (1) Nedim ÇAKIR ${ }^{2}$, (1) Leyla AKARTAŞ ${ }^{1}$ \\ ${ }_{1}^{1}$ Near East University Medical Sciences Institute, Department of Clinical Microbiology, Nicosia, Cyprus \\ ${ }^{2}$ Near East University Faculty of Medicine, Department of Infectious Diseases and Clinical Microbiology, Nicosia, Cyprus
}

\section{Abstract}

Introduction: Multiple resistance to antibiotics is a problem in modern medicine and acceptable definitions are needed to describe it. The widely accepted method for this purpose is the Multiple Drug Resistance (MDR) definition and the older but less used Multiple Antibiotic Resistance (MAR) indexing system. The aim of this study was to analyze their ability for comparing multiple resistance results for the same Enterobacteriaceae members obtained using these two methods and to investigate whether there is a need to improve these definitions.

Materials and Methods: Antimicrobial resistance test results of 665 Escherichia coli and 292 Klebsiella spp. strains isolated in the Clinical Microbiology Laboratory of our hospital were evaluated retrospectively. Resistance results were grouped under antibiotic categories and classified as multiple, extensively, and pan-drug resistance groups according to the MDR definition. MAR indices were determined by dividing the number of resistant antibiotics in both microorganism isolates separately and collectively by the number of antibiotics for which susceptibility was tested. The results were divided into subgroups according to the origin of the patients and the clinical samples obtained and were evaluated according to their total results. Than the two resistance classification methods were compared.

Results: Among the E. coli and Klebsiella spp. strains analyzed in this study, $45.86 \%$ and $40.06 \%$ of the strains were classified as multidrug-resistant according to the MDR definition, respectively. However, when these strains were evaluated with the MAR index method, it was found that the resistance rates were (from most to least resistant) 1.65\%,6.46\%, 10.97\%, 7.36\%, 6.61\%, and 11.12\% in E. coli and 5.13\%, 7.87\%, 8.56\%, 3.79\%, 4.10\%, and $8.21 \%$ percent in Klebsiella spp. Similar results were observed in subgroup analysis.

Conclusion: Our study demonstrates that the MAR index method, which is used less frequently in medical research, yields more detailed results than the commonly used MDR method and provides more objective outcomes since it expresses resistance results numerically.

Keywords: Extensively drug-resistant, XDR, pandrug-resistant, PDR, microbial task performance and analysis

\section{Öz}

Giriş: Antibiyotiklere çoklu direnç, epidemiyolojik ve klinik açıdan yakından izlenmesi gereken bir sorundur. Bu amaç için de kabul edilebilir tanımlar gereklidir. Bu konuda yaygın olarak kabul edilen yöntem "Çoklu İlaç Dirençleri" ve daha az kullanılan-ancak daha eski olan "çoklu antibiyotik direnç (ÇAD) indeksleri" tanımlarıdır. Bu çalışmada, aynı Enterobacteriaceae üyesi kökenlerin iki yöntemle saptanan çoklu direnç sonuçlarını karşılaştırarak dirençleri tanımlama güçlerini analiz etmek, böylece bu tanımları geliştirmeye gerek olup olmadığını araştırmak amaçlandı. Gereç ve Yöntem: Hastanemiz Klinik Mikrobiyoloji Laboratuvarı'ndan izole edilen 665 Escherichia coli ve 292 Klebsiella spp. kökeninin antimikrobiyal direnç testi sonuçları geriye dönük olarak değerlendirildi. Mikroorganizmalar hastaların geliş kaynaklarına ve elde

Cite this article as: Savaşan N, Çakır N, Akartaş L. Comparison of Definitions of Multiple Drug Resistance to Antibiotics and Its Alternative Multiple Antibiotic Resistance and Their Methodological. Mediterr J Infect Microb Antimicrob. 2019;8:34. 
edildikleri klinik örneklere göre gruplara ayrılarak ve toplam sonuçlarına göre değerlendirildi. Direnç sonuçları antibiyotik kategorileri altında toplanarak en az üç kategoriye dirençli mikroorganizmalar çoklu ilaç dirençli (ÇiD), en çok iki antibiyotiğe duyarlı kökenler yaygın ilaç direnci, tüm kategorilere dirençli kökenler ise tam ilaç direnci olarak sınıflandırıldı. Çoklu antibiyotik direnci çalışmasında ise her bir mikroorganizmanın dirençli olduğu antibiyotik sayısını toplam antibiyotik duyarlılık test sayısına bölerek direnç oranları saptadı. Sonuçlar onarlı direnç oranları şeklinde gruplandırıldı. Sonrasında bu iki direnç yöntemi birbiriyle kıyaslandı.

Bulgular: Çalışmamızda Escherichia coli ve Klebsiella spp. kökenlerinin sırasıyla \%45,86 ve \%40,06 oranında çiD olduğu saptandı. Buna karşı bu kökenler ÇAD indeksi yöntemiyle değerlendirildiğinde direnç oranlarının onarlı sistem halinde ve azalan sırasıyla $E$. coli kökenlerinde yüzde $\% 1,65, \% 6,46, \% 10,97, \% 7,36, \% 6,61, \% 11,12$ ve Klebsiella spp. kökenlerinde \%5,13, \%7,87, \%8,56, \%3,79, \%4,10, $\% 8,21$ oranında oldukları saptandı. Aynı sonuçların mikroorganizmaların gruplara ayrılmasından sonra da benzer şekilde devam ettikleri görüldü.

Sonuç: Sunulan çalışmada antibiyotiklerin direnç oranlarını araştırmada tıbbi araştırmalarda daha az kullanılan ÇAD indeksi yönteminin sıklıkla kullanılan ÇiD yönteminden daha ayrıntılı sonuçlar verdiği ve direnç sonuçlarını sayısal ifadelerle tanımladığı için daha nesnel değerlendirmelere olanak sağladığı sonucuna varıldı.

Anahtar Kelimeler: Yaygın ilaç direnci, XDR, tüm ilaçlara dirençli, PDR, mikrobiyal tanım performans analizi

\section{Introduction}

The development of multiple resistance to antibiotics is among the leading problems in modern medicine. This problem has become a global concern and caused substantial increases in treatment costs, morbidity, and mortality ${ }^{[1,2]}$. Antibiotic resistance is present in almost all microorganisms, especially members of the Enterobacteriaceae family. The World Health Organization (WHO) stated that multiple resistance is a problem shared worldwide and that it cannot be avoided, but merely delayed even with the appropriate use of antibiotics ${ }^{[3]}$. The WHO also points out that the development of resistance to multiple antibiotics in the same organism further complicates the existing resistance problem ${ }^{[4]}$.

Acceptable definitions are needed to control the problem of multiple resistance. Since the 1960s, the development of resistance to multiple antibiotics by bacteria has been regarded simply as "multiple resistance." However, it is clear that this simple definition is inadequate. For instance, if a microorganism is found to be resistant to a single carbapenem, can this microorganism be considered resistant to all other carbapenems? Resistance to how many antibiotics should qualify as "multiple resistance," and by what rationale? These and many similar questions pose issues that necessitate more widely accepted definitions.

On the other hand, the fact that a single resistance mechanism can confer resistance to multiple antibiotics or that resistance to a single antibiotic may be caused by multiple pathways makes it impossible to predict antibiotic multiresistance ${ }^{[5-9]}$. Therefore, it was deemed necessary to create definitions of multidrug-resistant (MDR) without considering its genotypic basis. The most widely accepted definition on this topic is that developed by Magiorakos et al. ${ }^{[10]}$, who proposed the terms MDR, extensively drug-resistant (XDR), pandrug-resistant (PDR), referring to them all briefly as "MDR".

In fact, this definition is not the first in this field. In 1982,
Krumperman ${ }^{[11]}$ superior script proposed a method he called "multiple antibiotic resistance indexing" (MAR index), which involves dividing the number of antibiotics to which an organism shows resistance by the number of antibiotics tested. For example, if an organism is resistant to 4 of 8 tested antibiotics, the index would be $4 / 8=0.5$. Accordingly, the most sensitive microorganism is described numerically as 0 (MAR index: $0 / X=0.00)$, whereas a completely resistant microorganism is described as 1 (MAR index: $X / X=1.00$ ) (refers the Magiorakos et al. ${ }^{[10]}$ definition of PDR). All intermediate resistance rates have values ranging between 0 and 1 . Moreover, in studies analyzing multiple microorganisms, Krumperman also described a single resistance value obtained by dividing the total instances of resistance by total number of tests, which was called the "total MAR index"[11].

Since the MAR index method was published in an applied environmental microbiology journal (Applied and Environmental Microbiology), the study did not gain sufficient readership in the medical field. As a result, the method has been mostly used by environmental microbiologists and epidemiologists ${ }^{[11,12]}$.

In contrast, the MDR method was proposed by a working group established through a joint initiative by the European Centre for Disease Prevention and Control and the United States Centers for Disease Control and Prevention ${ }^{[10]}$, and has thus found widespread use in medicine.

The aim of this study was to analyze the MDR definition in comparison with the MAR indexing method and to investigate to what degree these two methods can identify multiple resistance in microorganisms, determine which definition provides more detailed and comprehensive information, and evaluate their respective strengths and limitations.

\section{Materials and Methods}

In this study, MAR index and MDR values were determined and compared for 665 Escherichia coli strains from 595 patients and 
292 Klebsiella strains from 269 patients, isolated from various clinical samples (Table 1) in the Faculty of Medicine Central Laboratory of our university between September 2015 and July 2017. Since our hospital is a small-scale center in terms of number of patients, sampling was not performed and all of the isolated microorganisms were included in the study.

The study data were retrieved via retrospective chart review.

Inclusion and exclusion criteria were as follows:

- Bacteria isolated from different clinical samples of the same patient or from the same sample type isolated at an interval of at least 10 days or displaying different antibiotic resistance patterns were included in the study.

- The same bacteria isolated from cultures repeated within 10 days were excluded.

- If an antibiotic was tested on fewer than half of the overall bacterial strains/patients, this antibiotic was excluded from the study.

These included:

- Antibiotics excluded from the study for both groups: Cefazolin, cefoxitin, colistin, nitrofurantoin, netilmicin, piperacillin, fosfomycin, ticarcillin/clavulanate, and levofloxacin.

- Antibiotics excluded from the E. coli analyses only: Cefuroxime axetil, tigecycline.

- Antibiotics excluded from the Klebsiella spp. analyses only: Cefaclor, cefotaxime, cefoperazone/sulbactam.

Microorganisms were identified by routine bacteriological methods using Phoenix BD 100 Automated Microbiology System (Becton Dickinson, New Jersey, USA). Antibiotic susceptibility testing was performed using 0xoid combination disk test (Oxoid Limited Hampshire, UK) and the results were evaluated according to EUCAST (European Committee on Antimicrobial Susceptibility Testing) guidelines ${ }^{[13]}$.

If an organism was resistant or less sensitive to any one of the antimicrobial agents, this microorganism was classified as resistant for both methods.

The antimicrobial agents used in the tests for MDR methods were grouped into antimicrobial categories based on the molecular structure similarities as described by Magiorakos et al. ${ }^{[10]}$ Microorganisms resistant to 3 or more antibiotic categories were defined as MDR, those sensitive to 2 or fewer antibacterial categories were defined as XDR, and those resistant to all categories were defined as PDR.

MAR index was calculated for the microorganisms as described by Krumperman ${ }^{[11]}$. Antibiotic categories were not used in the MAR indexing method and the results were evaluated separately. MAR index results were grouped according to the decimal system $(0.01-0.09,0.10-0.19 \ldots 0.90-0.99$ and 1.00$)$. With this method, fully sensitive strains and single- and double-resistant strains, which are not described in the Magiorakos method, were named according to the number of drugs they were resistant to. These "undefined areas" were excluded by Magiorakos.

A simulation chart was created to compare the two methods (Graphic 1). In this table, proportions were made for the MAR index by dividing the numbers from 0 to 19 by the total number of antibiotics, 19 (0/19, 1/19, 2/19 ... 18/19, 19/19). These values were used as the limits of groups of 10 when grouping the MAR indices. The equivalents of these 19 antibiotics in the MDR system were marked as checkboxes.

E. coli and Klebsiella spp. and their resistance results were divided into community-acquired, hospital-acquired, and total, based on patient presentation.

Since non-urine samples were sporadically distributed and few in number, the microorganisms' clinical characteristics were analyzed after grouped according to sample source as urine and non-urine. Resistance results were evaluated separately for both groups.

The total MAR index was calculated separately for each microorganism by dividing the total number of resistant antibotics in all microorganisms tested by only MAR index by the total number of antibiotic susceptibilty tests for all microorganisms. The values obtained were shown in all tables.

To investigate the use of MDR and MAR indexing methods in medical literature, searches were performed to determine how many times these words were cited in the Google search engine on August 20,2019, and what proportion of publications in the US National Institutes of Health PubMed database that included these terms were in the medical literature. The keywords used for MDR and MAR indexing were "MDR, Magiorakos" and "MAR indexing, Krumperman" in Google and "multidrug resistance" and "multiple antibiotic resistance" in PubMed, respectively. The articles in PubMed were also analyzed to determine how many were from the medical field.

Table 1. Distribution of clinical samples that yielded the study strains Escherichia coli and Klebsiella spp.

\begin{tabular}{l|l|l}
\hline Sample type & Klebsiella n (\%) & $\begin{array}{l}\text { Escherichia coli } \\
\text { n (\%) }\end{array}$ \\
\hline Urine & $164(56.16)$ & $550(82.71)$ \\
\hline Sputum/bronchial lavage & $51(17.46)$ & $16(2.41)$ \\
\hline Aspiration fluid & $25(8.56)$ & $16(2.41)$ \\
\hline Blood & $18(6.01)$ & $29(4.36)$ \\
\hline Abscess/wound material & $16(5.47)$ & $16(2.41)$ \\
\hline Catheter tip & $12(4.10)$ & $11(1.65)$ \\
\hline Other & $6(2.05)$ & $27(3.94)$ \\
\hline Total & 292 & 665
\end{tabular}




\section{Statistical Analysis}

Statistical methods were not used in this descriptive comparative study.

\section{Results}

Types of the clinical samples are summarized in Table 1. As seen in Table 1, more than half of both of microorganisms were isolated from urine samples. This was followed by respiratory samples such as sputum and bronchial lavage for Klebsiella. As the proportion of non-urine samples was below 5\% for E. coli, these samples were not evaluated separately.

For each microorganism group, MDR, MAR index, and total MAR index values based on patient presentation and for all samples are shown in Tables 2 and 3.

In total, $45.86 \%$ of all E. coli strains were MDR according to Magiorakos' definition ${ }^{[10]}$, with this rates being higher among inpatients than outpatients (65.00\% vs. $34.54 \%)$. When total MAR indices were grouped according to resistance rates $(0.99 \rightarrow$

\begin{tabular}{|c|c|c|c|c|c|c|c|c|c|c|c|c|c|c|c|c|c|c|c|c|}
\hline$(* *)$ & 0 & 1 & 2 & 3 & 4 & 5 & 6 & 7 & 8 & 9 & 10 & 11 & 12 & 13 & 14 & 15 & 16 & 17 & 18 & 19 \\
\hline$U A\left({ }^{* * *}\right)$ & & & $(*)$ & & & & & & & & & & & & & & & & & \\
\hline & & & & & & & & & & & & & & & & & & & & \\
\hline \multirow{2}{*}{\multicolumn{21}{|c|}{ MDR }} \\
\hline & & & & & & & & & & & & & & & & & & & & \\
\hline \multicolumn{21}{|l|}{ XDR } \\
\hline \multicolumn{21}{|l|}{ PDR } \\
\hline MAR index & 0 & $\begin{array}{l}\text { ్ֶ } \\
\text { Oे }\end{array}$ & $\stackrel{\stackrel{2}{\circ}}{\circ}$ & $\frac{\hat{n}}{0}$ & & 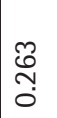 & $\frac{n}{m}$ & $\begin{array}{l}\text { o } \\
\text { ల్ } \\
0\end{array}$ & $\begin{array}{l}\overline{7} \\
\text { ¿ }\end{array}$ & 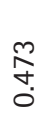 & 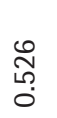 & 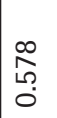 & סु. & $\begin{array}{l}\mathbb{\infty} \\
0 \\
0\end{array}$ & $\begin{array}{l}\stackrel{\infty}{\hat{n}} \\
\hat{0}\end{array}$ & $\begin{array}{l}\stackrel{\infty}{\infty} \\
\stackrel{0}{0}\end{array}$ & $\mid \begin{array}{c}\bar{q} \\
\vdots \\
0 \\
0\end{array}$ & $\begin{array}{l}\text { पे } \\
\stackrel{0}{\circ} \\
\stackrel{0}{0}\end{array}$ & $\begin{array}{l}\text { fo } \\
\stackrel{\circ}{0}\end{array}$ & 8 \\
\hline
\end{tabular}

Graphic 1. Simulation of the relationship between multiple antibiotic resistances index and Magiorakos definition

${ }^{*}$ Column indicates resistance types. Rows indicates amount of resistances

**White boxes: Sensitive strains. Grey boxes: Resistant strains

***Undefined area.

UA: Undefined area, MDR: Multidrug-resistant, XDR: Extensively drug-resistant, PDR: Pan drug-resistant, MAR: Multiple antibiotic resistances

Table 2. Multiple antibiotic resistance index and Magiorakos definition results for Escherichia coli according to distributions of patient presentation and total resistance results

\begin{tabular}{|c|c|c|c|c|c|c|c|}
\hline \multirow{2}{*}{ MAR range } & \multirow{2}{*}{$\begin{array}{l}\text { Magiorakos } \\
\text { definition }\end{array}$} & \multicolumn{2}{|c|}{ Outpatient $(n=359)$} & \multicolumn{2}{|l|}{ Inpatient $(n=306)$} & \multicolumn{2}{|c|}{ Total samples $(n=665)$} \\
\hline & & MAR index & Magiorakos & MAR index & Magiorakos $\left({ }^{*}\right)$ & MAR index & Magiorakos $\left({ }^{*}\right)$ \\
\hline 1 & PDR & & & 0 & 0 & & \\
\hline $0.99-0.90$ & \multirow{2}{*}{ XDR } & 0 & & 0 & \multirow{2}{*}{0.6} & 0 & \\
\hline $0.89-1.80$ & & 0 & & 0.6 & & 0.6 & \\
\hline $0.79-0.70$ & \multirow{6}{*}{ MDR } & 0.02 & \multirow{6}{*}{34.54} & 3.3 & \multirow{6}{*}{65.0} & 1.65 & \multirow{6}{*}{45.86} \\
\hline $0.60-0.69$ & & \begin{tabular}{|l|}
3.62 \\
\end{tabular} & & 10.0 & & 6.46 & \\
\hline $0.50-0.59$ & & \begin{tabular}{|l|}
7.24 \\
\end{tabular} & & 17.3 & & 10.97 & \\
\hline $0.40-0.49$ & & \begin{tabular}{|l|}
6.12 \\
\end{tabular} & & 8.60 & & 7.36 & \\
\hline $0.30-0.39$ & & \begin{tabular}{|l|}
6.40 \\
\end{tabular} & & 8.30 & & 6.61 & \\
\hline $0.20-0.29$ & & 7.52 & & 16.60 & & 11.12 & \\
\hline $0.10-0.19$ & Double-resistant & 15.87 & 5.29 & 7.0 & 7.0 & 14.58 & 5.5 \\
\hline $0.09-0.01$ & Single-resistant & 39.74 & 16.99 & 7.60 & 7.60 & 8.42 & 16.90 \\
\hline 0 & Pan-sensitive & 43.17 & 42.80 & 20.0 & 20.30 & 32.48 & 32.48 \\
\hline $\begin{array}{l}\text { Total MAR } \\
\text { indices }\end{array}$ & & 972/5821:0.167 & & 1498/4859:0.308 & & 2407/10614:0.227 & \\
\hline
\end{tabular}

$\left.{ }^{*}\right)$ Magiorakos' definitions of multiple drug resistance.

MAR: Multiple antibiotic resistance, PDR: Pandrug-resistant, XDR: Extensively drug-resistant, MDR: Multidrug-resistant 
0 ), the number of strains detected in each group icreased ( $0 \rightarrow$ $32.48 \%$ ) as resistance rates desreased. The same phenomenon was observed in both outpatients and inpatients. Total MAR indices, which are the main difference between the Krumperman method and MDR system, were higher among inpatients compared to outpatients. This was likely attributable to the exposure of inpatients to multiresistant organisms more commonly in the hospital environment.

Klebsiella spp. had a total MDR rate of $40.06 \%$, similar to $E$. coli, and also exhibited higher resistance in inpatients $(46.70 \%$ vs. 29.09\%). The total MAR indices for Klebsiella were found to have different rates but had similar characteristics.

Table 3. Multiple antibiotic resistance index and Magiorakos definition (multidrug-resistant) results of Klebsiella spp. according to distribution of patients' presentation and total resistance results

\begin{tabular}{|c|c|c|c|c|c|c|c|}
\hline \multirow{2}{*}{$\begin{array}{l}\text { MAR index } \\
\text { range }\end{array}$} & \multirow[b]{2}{*}{ Magiorakos definition } & \multicolumn{2}{|c|}{ Outpatient $(n=110)$} & \multicolumn{2}{|c|}{ Inpatient $(n=182)$} & \multicolumn{2}{|l|}{ Total $(n=292)$} \\
\hline & & MAR index & $\begin{array}{l}\text { Magiorakos } \\
\left({ }^{*}\right)\end{array}$ & MAR index & \begin{tabular}{|l} 
Magiorakos \\
$\left({ }^{*}\right)$
\end{tabular} & MAR index & $\begin{array}{l}\text { Magiorakos } \\
\left({ }^{*}\right)\end{array}$ \\
\hline 1 & PDR & & & 0 & & 0 & \\
\hline $0.99-0.90$ & \multirow{2}{*}{ XDR } & & & 0 & \multirow{2}{*}{0.5} & 0 & \multirow{2}{*}{0.37} \\
\hline $0.89-1.80$ & & & & 0.90 & & 1.60 & \\
\hline $0.79-0.70$ & \multirow{6}{*}{ MDR } & 1.81 & \multirow{6}{*}{29.09} & 7.14 & \multirow{6}{*}{46.70} & 5.13 & \multirow{6}{*}{40.06} \\
\hline $0.60-0.69$ & & 5.45 & & 9.34 & & 7.87 & \\
\hline $0.50-0.59$ & & 5.45 & & 10.43 & & 8.56 & \\
\hline $0.40-0.49$ & & 0.9 & & 5.49 & & 3.76 & \\
\hline $0.30-0.39$ & & 5.45 & & 4.94 & & 4.10 & \\
\hline $0.20-0.29$ & & 8.18 & & 8.24 & & 8.21 & \\
\hline $0.10-0.19$ & Double-resistant & 13.63 & 6.36 & 14.83 & 7.14 & 14.38 & 6.84 \\
\hline $0.09-0.01$ & Single-resistant & 24.54 & 30 & 18.68 & 24.72 & 20.89 & 26.71 \\
\hline 0 & Pan-sensitive & 34.54 & 34.54 & 20.87 & 20.87 & 26.02 & 26.02 \\
\hline $\begin{array}{l}\text { Total MAR } \\
\text { index }\end{array}$ & & 271/1667:0.162 & & 728/2615:0.278 & & 999/4282:0.233 & \\
\hline
\end{tabular}

$\left(^{*}\right)$ Magiorakos' definitions of multiple drug resistance.

MAR: Multiple antibiotic resistance, PDR: Pandrug-resistant, XDR: Extensively drug-resistant, MDR: Multidrug-resistant

Table 4. Distributions of Escherichia coli multiple antibiotic resistance index and magiorakos definition results according to clinical samples

\begin{tabular}{|c|c|c|c|c|c|}
\hline \multirow{2}{*}{ MAR index range } & \multirow{2}{*}{ Magiorakos definition } & \multicolumn{2}{|c|}{ Non-urine $(n=115)$} & \multicolumn{2}{|l|}{ Urine $(n=550)$} \\
\hline & & MAR index & Magiorakos & MAR index & Magiorakos $\left({ }^{*}\right)$ \\
\hline 1 & PDR & 0 & \multirow{2}{*}{0} & & \multirow{2}{*}{0} \\
\hline $0.99-0.90$ & \multirow{2}{*}{ XDR } & 0 & & & \\
\hline $0.89-1.80$ & & 1.17 & & & \\
\hline $0.79-0.70$ & \multirow{6}{*}{ MDR } & 6.90 & \multirow{6}{*}{62.60} & 5.40 & \multirow{6}{*}{44.00} \\
\hline $0.60-0.69$ & & 12.20 & & 5.09 & \\
\hline $0.50-0.59$ & & 11.30 & & 1.07 & \\
\hline $0.40-0.49$ & & 9.56 & & 7.09 & \\
\hline $0.30-0.39$ & & 6.00 & & 7.09 & \\
\hline $0.20-0.29$ & & 15.60 & & 10.00 & \\
\hline $0.10-0.19$ & Double-resistant & 14.70 & 7.80 & 14.54 & 5.60 \\
\hline $0.09-0.01$ & Single-resistant & 7.80 & 15.60 & 8.54 & 14.00 \\
\hline 0 & Fully sensitive & 13.90 & 13.90 & 36.36 & 36.36 \\
\hline Total MAR index & & 615/1838:0.334 & & 1855/8839:0.204 & \\
\hline
\end{tabular}

$\left(^{*}\right)$ Magiorakos' definitions of multiple drug resistance.

MAR: Multiple antibiotic resistance, PDR: Pandrug-resistant, XDR: Extensively drug-resistant, MDR: Multidrug-resistant 
Distributions of E. coli and Klebsiella spp. by clinical sample are shown in Table 4 and Table 5, respectively. For both microorganisms, non-urine samples had higher MDR value and total MAR indices than urine samples. Among the MAR indices, the fully sensitive and single-resistant groups represented the largest proportions for both microorganisms.

Graphic 2 and 3 juxtapose the MAR index and MDR values obtained for E. coli and Klebsiella strains, respectively. Both

Table 5. Distributions of Klebsiella spp. multiple antibiotic resistance index and magiorakos definition results according to clinical samples

\begin{tabular}{|c|c|c|c|c|c|}
\hline \multirow{2}{*}{ MAR index range } & \multirow{2}{*}{ Magiorakos definition } & \multicolumn{2}{|c|}{ Non-urine $(n=129)$} & \multicolumn{2}{|l|}{ Urine $(n=163)$} \\
\hline & & MAR index & Magiorakos & MAR index & Magiorakos $\left({ }^{*}\right)$ \\
\hline 1 & PDR & 0 & 0 & 0 & 0 \\
\hline $0.99-0.90$ & \multirow[t]{2}{*}{ XDR } & 0 & \multirow{2}{*}{1} & 0 & \\
\hline $0.89-1.80$ & & 1 & & 0 & \\
\hline $0.79-0.70$ & \multirow{6}{*}{ MDR } & 8.52 & \multirow{6}{*}{41.86} & 2.45 & \multirow{6}{*}{38.65} \\
\hline $0.60-0.69$ & & 9.30 & & 6.74 & \\
\hline $0.50-0.59$ & & 6.20 & & 10.42 & \\
\hline $0.40-0.49$ & & 2.32 & & 4.90 & \\
\hline $0.30-0.39$ & & 2.32 & & 5.52 & \\
\hline $0.20-0.29$ & & 8.52 & & 7.97 & \\
\hline $0.10-0.19$ & Double-resistant & 16.27 & 4.65 & 12.88 & 8.58 \\
\hline $0.09-0.01$ & Single-resistant & 15.50 & 22.48 & 25.15 & 28.83 \\
\hline 0 & Fully sensitive & 28.68 & 28.68 & 23.92 & 23.92 \\
\hline Total MAR index & & $389 / 1503: 0.258$ & & 541/3184:0.169 & \\
\hline
\end{tabular}

$\left(^{*}\right)$ Magiorakos' definitions of multiple drug resistance.

MAR: Multiple antibiotic resistance, PDR: Pandrug-resistant, XDR: Extensively drug-resistant, MDR: Multidrug-resistant

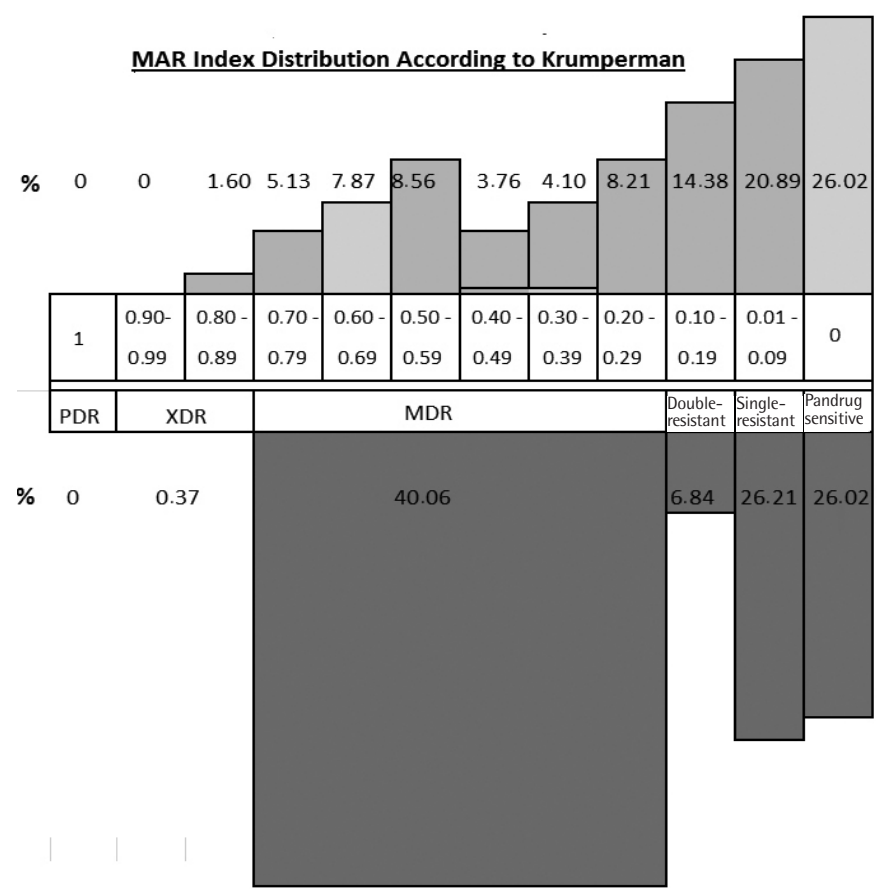

MDR Distribution According to Magiorakos

Graphic 2. Comparison of multiple antibiotic resistances index and Magiorakos definition (multidrug-resistant) results in Escherichia coli

MAR: Multiple antibiotic resistance, PDR: Pandrug-resistant, XDR: Extensively drugresistant, MDR: Multidrug-resistant

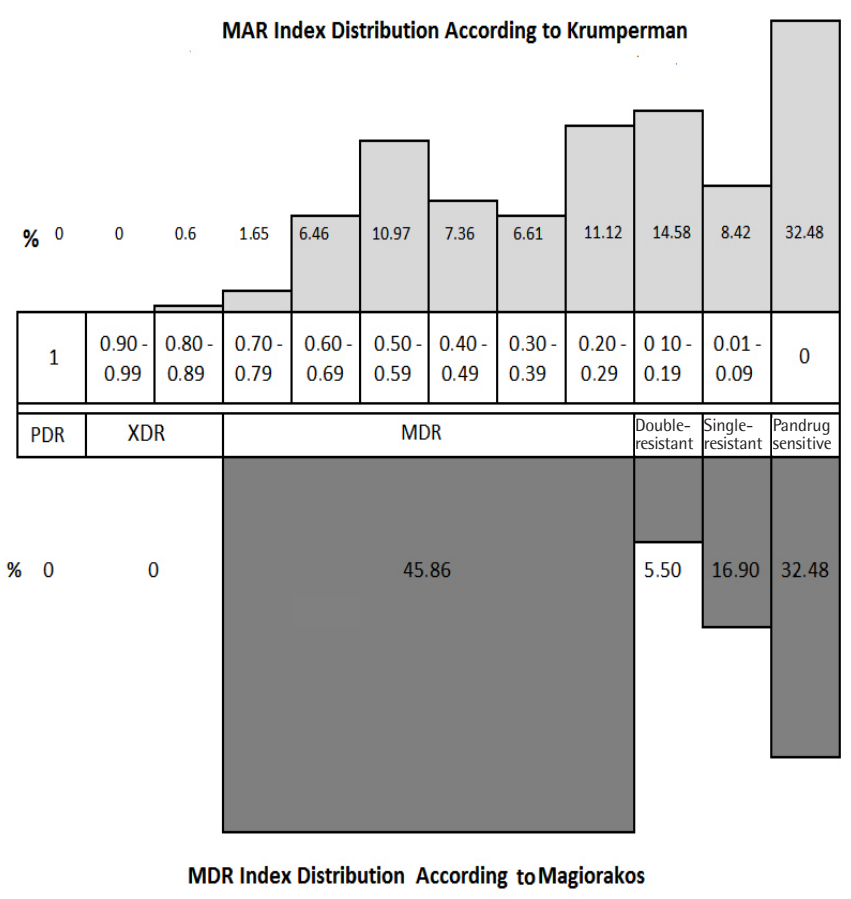

Graphic 3. Comparison of multiple antibiotic resistance index and Magiorakos definition (multidrug-resistant) results in Klebsiella spp.

MAR: Multiple antibiotic resistance, PDR: Pandrug-resistant, XDR: Extensively drugresistant, MDR: Multidrug-resistant 
graphics show that the single Magiorakos MDR category corresponds to a more detailed representation in Krumperman's method. Both microorganisms decreased in proportion as resistance increased. This feature also extended to the double-/ single-resistant and fully sensitive groups that were not defined by Magiorakos.

The search results for scientific studies related to the MAR index and MDR were as follows: MAR indexing was cited 770 times and MDR method was cited 4770 times in the Google search engine. Of the papers in PubMed that contained "MAR index," 23\% were medical papers and 77\% were non-medical, environmental microbiology papers, while of those using the term "MDR," 88\% were medical papers and $12 \%$ were non-medical papers.

\section{Discussion}

Microorganisms with MAR has been a growing problem since the 1960s and has become pandemic in nature ${ }^{[3,4,14]}$. Therefore, monitoring the spread of these strains within individual societies has become imperative. Despite Krumperman's clear definition of multiple resistance, no definition achieved widespread acceptance until the definition proposed by Magiorakos et al. ${ }^{[10]}$ in 2012. During this period, any form of multiple resistance was referred to by this term without offering a complete/standard definition. For instance, there are several publications defining MDR as resistance to 2 of 3 different antibiotic categories such as beta-lactams, aminoglycosides, and fluoroquinolones. In 2012, just before the introduction of the Magiorakos definition, Subramani and Vinglesh ${ }^{[15]}$ performed a study comparing the proportions of Staphylococcus aureus strains they evaluated as MDR (resistant to at least 2 of 3 antibiotic classes) with those strains' MAR index values and reported $50 \%$ agreement between the two methods. Their study is one of the rare comparative analyses conducted on this subject, and is similar to our study in that it demonstrated that the two definitions are not fully compatible. However, the method they used is very different from Magiorakos' method and overlooks resistance to many antibiotics.

According to the results of our study as seen in Graphic 2 and 3 , the MAR index is more advantageous over MDR classification in terms of objectivity and interpretability. For example, it is immediately clear that an organism with a MAR index of 0.6 is more resistant than one with a MAR index of 0.35 . However, these two microorganisms are indiscriminately referred to as MDR and cannot be compared in Magiorakos' system ${ }^{[10]}$.

In MAR indexing, each antibiotic is evaluated separately and not according to their antibiotic classes. The fact that the MDR system groups ${ }^{[10]}$ antibacterial agents into classes and considers a microorganism resistant to all antibiotics in a class when resistance to a single agent is detected, is a significant difference in methodology. Is such a practice always correct? The answer to this question warrants discussion. For example, Becnel Boyd et al. ${ }^{[16]}$ reported that fluoroquinolones can be considered equivalent in terms of clinical sensitivity or resistance, but the minimal inhibitory concentrations of fluoroquinolones may vary due to differences in molecular structure. A similar situation was also reported in this group due to aminoglycoside heteroresistance ${ }^{[17]}$. Kanazawa et al. ${ }^{[18]}$ also described Enterobacteriaceae strains that were sensitive to imipenem but resistant to meropenem. Different sensitivity/ resistance values obtained in different laboratory studies for antibiotics in the same class reduces the sense of reliability during clinical practice. Magiorakos et al. ${ }^{[10]}$ solved this problem with the principle that detection of resistance to any antibiotic in a an antibiotic class requires the assumption of resistance to all members of that class. However, this categorization may also lead to inaccurate and unrealistically high resistance estimations. In our study, we found that the same resistance results of two microorganisms yielded different ratios using these two different methods and that this discrepancy continued for inpatients/outpatients and sample type subgroups. We believe that this is attributable to the classification of antibiotics in the Magiorakos method. For example, while the total MDR rate was $45.86 \%$ in $E$. coli, the corresponding total MAR index (in the $0.20-0.79$ range) was $44.17 \%$. Similar results were obtained with other resistance patterns and for Klebsiella. The opposite may also be true. A single resistance mechanism such as betalactamase production can cause resistance to many betalactams and thus be perceived as extensive resistance. In future studies, methods based on genotypic diversity rather than the phenotypic character of resistance may also be necessary for both of these definitions. It is natural that definitions for full sensitivity and single resistance are not included in Magiorakos et al.'s ${ }^{[10]}$ MDR definition studies. However, we believe that double resistance should be added to this definition. We could not identify a concrete reason for excluding a definition of double resistance from the MDR categorization system ${ }^{[10]}$. In contrast, the MAR indexing method ${ }^{[11]}$ describes all resistance patterns, from complete sensitivity to complete resistance. Areas left undefined in the MDR system ${ }^{[10]}$ were evaluated as $0 / X, 1 / X$, and 2/X ratios in MAR indexing ${ }^{[11]}$. As can be seen in both methods, panresistance defined by Magiorakos ${ }^{[10]}$ is too common to be excluded from the epidemiological studies of single and double resistance outcomes, and MAR indexing ${ }^{[11]}$ results of these give significant epidemiological results.

How newly introduced antibiotics should be incorporated into the MDR method (Magiorakos definition) has never been described. The fact that the categories have already been determined and described may lead to differences in practice. There is no such limitation with the MAR indexing method. This limitation may 
preclude the use of the MDR system in retrospective clinical/ epidemiological studies. The inability to test all antibiotics on the list due to daily operation limitations in the laboratory limits the evaluation of the results. We had the same difficulty when evaluating MDR results. In MDR evaluation, we had to modify the method by excluding some of the antibiotics in the list from the study, which is an important limitation of our study.

Another important difference between these two methods is the strength and detailing capacity of the definitions. The aspect of the Magiorakos method is mostly criticised that resistance to a broad range of (3-14) antibiotics, is lumped into the single category of "MDR." While $45.86 \%$ of $E$. coli strains in our study were MDR, the proportions corresponding to the decreasing MAR index values provide more detail $(1.65,6.46,10.97,7.36$, 6.61 , and $11.12 \%)$. The same finding was noted when the samples were grouped according to patient presentation and sample type. Instances of resistance represented by a single MDR value are expressed as 6 different results in MAR indexing. Graphics 2 and 3 reflect how the resistance rates within this range vary in Enterobacteriaceae. The same problem is also seen at a smaller scale in the definition of the double-resistant group in XDR. With such data, it is clear that MAR indexing provides an indispensable luxury of information in epidemiological studies.

An additional feature of Krumperman's MAR indexing is the total MAR index dfinition ${ }^{[11]}$. This number can provide an idea about total resistance among numerous microorganisms in epidemiological studies. In this context, it appears that Klebsiella spp. are more resistant than E.coli in our study. Total MAR index is a superior method because it gives an objective and numerical result for microorganismic resistance status with a single evaluation. However, Krumperman's method also has some shortcomings. This method does not bring discipline to the number and types of antibiotics to be used in the test. This is a problem that precludes meta-analyses including similar studies.

The usage and citation of both methods in subsequent studies were faithful to the sources' scientific areas that first defined them. For example, at the time of this study, MDR was cited 4,770 times and MAR index was cited only 770 times according to Google. According to PubMed, the majority of papers including "MAR" were non-medical, while the majority of papers including "MDR" were medical. These papers outnumbered nonmedical sources by 6 fold. None of the medical and non-medical papers that used either method explains why these methods were selected.

\section{Conclusion}

In this study we retrospectively compared MDR classification and MAR indexing in E. coli and Klebsiella strains. The results of MAR indexing were more objective and informative about resistance. Although the MDR method can be used in wellplanned studies, MAR indexing may enable retrospective analyses and even the evaluation of unplanned results. Further studies are required on the applicability of this method in clinical outcomes. Nevertheless, it is certain that new definitions are required. Repeating this study with other microorganisms will be further enlightening.

\section{Acknowledgement}

We would like to thank Dr. Kaya Süer and Emrah Güler for their assistance with data collection.

Ethics

Ethics Committee Approval: The ethics committee approval was not obtained as it was a retrospective laboratory study.

Informed Consent: The informed consent was not obtained as no patient was evaluated.

Peer-review: Externally and internally peer-reviewed.

\section{Authorship Contributions}

Surgical and Medical Practices: N.S., N.Ç., L.A., Concept: N.Ç., Design: N.Ç., Data Collection or Processing: N.Ç., L.A., Analysis or Interpretation: N.Ç., L.A., Literature Search: N.S., L.A., Writing: N.Ç.

Conflict of Interest: No conflict of interest was declared by the authors.

Financial Disclosure: The authors declared that this study received no financial support.

\section{References}

1. Karam G, Chastre J, Wilcox MH, Vincent JL. Antibiotic strategies in the era of multidrug resistance. Crit Care. 2016;22;20:136.

2. Thaden JT, Li Y, Ruffin F, Maskarinec SA, Hill-Rorie JM, Wanda LC, Reed SD, Fowler VG Jr. Increased Costs Associated with Bloodstream Infections Caused by Multidrug-Resistant Gram-Negative Bacteria Are Due Primarily to Patients with Hospital-Acquired Infections. Antimicrob Agents Chemother. 2017;61:1709-16.

3. World Health Organization Factsheet of antibiotic resistances. The last accessed date: 05.02.2018. Available from: https://www.who.int/newsroom/ factsheets/detail/antibiotic-resistance

4. World Health Organization Global Action plan (Together with FAO and OIE) The last accessed date: 2017.11.03. Available from: https://www.who. int/antimicrobialresistance/global-action-plan/UpdatedRoadmap-GlobalFramework-for-DevelopmentStewardship-to-combatAMR_2017_11_03

5. Alekshun MN, Levy SB. Molecular Mechanisms of Antibacterial Multidrug Resistance. Cell. 2007;128:1037-50.

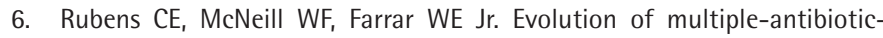
resistance plasmids mediated by transposable plasmid deoxyribonucleic acid sequences. J Bacteriol. 1979;140:713-9.

7. Bottery MJ, Wood AJ, Brockhurst MA. Selective Conditions for a Multiple Drug Resistance Plasmid Depend on the Sociality of Antibiotic Resistance. Antimicrob Agents Chemother. 2016;60:2524-7.

8. Poole K. Efflux-mediated antimicrobial resistance. J Antimicrob Chemother 2005;56:20-51. 
9. Cerceo $E_{1}$ Deitelzweig $S B$, Sherman BM, Amin AN. Multidrug-Resistant Gram Negative Bacterial Implications for Clinical Practice, and Emerging Treatment Options. Microb Drug Resist. 2016;22:412-31.

10. Magiorakos AP, Srinivasan A, Carey RB, Carmeli $Y$, Falagas ME, Giske CG, Harbarth S, Hindler JF, Kahlmeter G, Olsson-Liljequist B, Paterson DL, Rice LB, Stelling J, Struelens MJ, Vatopoulos A, Weber JT, Monnet DL. Multidrug resistant, extensively drug-resistant and pandrug-resistant bacteria: an international expert proposal for interim standard definitions for acquired resistance. Clin Microbiol Infect. 2012;18:268-81.

11. Krumperman PH. Multiple antibiotic resistance indexing of Escherichia coli to identify high-risk sources of fecal contamination of foods. Appl Environ Microbiol. 1983;46:165-70.

12. Naik OA, Shashidhar R, Rath D, Bandekar JR, Rath A. Characterization of multiple antibiotic resistance of culturable microorganisms and metagenomic analysis of total microbial diversity of marine fish sold in retail shops in Mumbai, India. Environ Sci Pollut Res Int. 2018;25:6228-39.

13. Matuschek E, Brown DF, Kahlmeter G. Development of the EUCAST disk diffusion antimicrobial susceptibility testing method and its implementation in routine microbiology laboratories. Clin Microbiol Infect. 2014;20:255-66.
14. van Duin D, Paterson DL. Multidrug-Resistant Bacteria in the Community: Trends and Lessons Learned. Infect Dis Clin North Am. 2016;30:377-90.

15. Subramani S, Vignesh S. MAR Index Study and MDR Character Analysis of a few Golden Staph Isolates. Asian Journal of Pharmacy and Life Science. 2012;2:151-4.

16. Becnel Boyd L, Maynard MJ, Morgan-Linnell SK, Horton LB, Sucgang R, Hamill RJ, Jimenez JR, Versalovic J, Steffen D, Zechiedrich L. Relationships among ciprofloxacin, gatifloxacin, levofloxacin, and norfloxacin MICs for fluoroquinolone resistant Escherichia coli clinical isolates. Antimicrob Agents Chemother. 2009;53:229-34.

17. Shannon KP, Phillips I, King BA. Aminoglycoside resistance among Enterobacteriaceae and Acinetobacter species. J Antimicrob Chemother. 1978;4:131-42.

18. Kanazawa $S$, Sato $T$, Kohira $N$, Ito-Horiyama $T$, Tsuji $M$, Yamano $Y$. Susceptibility of Imipenem-Susceptible but Meropenem-Resistant bla(IMP-6) Carrying Enterobacteriaceae to Various Antibacterials, Including the Siderophore Cephalosporin Cefiderocol. Antimicrob Agents Chemother. 2017;61:e00576-17. 